\title{
BADANIA PORÓWNAWCZE URZĄDZEŃ PRZEZNACZONYCH DO CIĄGŁEGO POMIARU WSPÓŁCZYNNIKA TARCIA NAWIERZCHNI ELEMENTÓW FUNKCJONALNYCH LOTNISK
}

\author{
Mariusz Wesołowski ${ }^{\bowtie}$, Piotr Barszcz, Krzysztof Blacha \\ Instytut Techniczny Wojsk Lotniczych, Warszawa
}

\begin{abstract}
STRESZCZENIE
Urządzenia mierzące współczynnik tarcia muszą gwarantować poprawność uzyskiwanych wyników, gdyż od oceny właściwości przeciwpoślizgowych nawierzchni lotniskowych zależy decyzja podjęta przez pilota o sposobie wykonania manewru lądowania (Jaźwiński i Borgoń, 1989). Przyjęta powtarzalność pomiarów na poziomie $\pm 0,03$ oraz odtwarzalność na poziomie $\pm 0,07$ nie jest warunkiem wystarczającym do akceptacji systemu pomiarowego. W artykule przedstawiono podejście do oceny systemów mierzących współczynnik tarcia nawierzchni elementów funkcjonalnych lotnisk. Pomiary dla określonych warunków przeprowadzono w 10 seriach na nawierzchniach wykonanych z betonu cementowego i asfaltowego, przy prędkościach 65 i $95 \mathrm{~km} \cdot \mathrm{h}^{-1}$, w warunkach „na sucho” i „na mokro”. Założenie o normalności rozkładów zweryfikowano na podstawie testu Shapiro-Wilka, analizując statystykę $W$. Z przeprowadzonych badań wynika, że współczynnik tarcia zmierzony z wykorzystaniem testerów tarcia biorących udział w badaniach osiągnął dla tych samych warunków badawczych różne wartości. Mając na uwadze tester odniesienia, wykreślono proste regresji w celu wyznaczenia skorygowanego współczynnika tarcia.
\end{abstract}

Słowa kluczowe: nawierzchnia lotniskowa, tester tarcia, właściwości przeciwpoślizgowe

\section{WSTĘP}

Właściwości przeciwpoślizgowe charakteryzują przyczepność opony statku powietrznego do nawierzchni i jest to zdolność do wytwarzania siły tarcia pomiędzy nawierzchnią elementu funkcjonalnego lotniska a kołami statku powietrznego w warunkach wzajemnego poślizgu. Na przyczepność wpływa rodzaj nawierzchni i jej stan, obecność zanieczyszczeń oraz warunki atmosferyczne w rejonie lotniska (Wytyczne nr 2 Prezesa Urzędu Lotnictwa Cywilnego z dnia 25 stycznia 2016 r. w sprawie metod oceny, pomiaru oraz raportowania stanu nawierzchni drogi startowej (Dz. Urz. Urzędu Lotnictwa Cywilnego z 2016 poz. 6)). Pomiar współczynnika tarcia nawierzchni lotniskowej może być wykonywany na mokro (pomiar z podawaniem wody pod koło pomiarowe) lub na sucho (pomiar bez podawania wody pod koło pomiarowe), w zależności od założeń badawczych. Zasady prowadzenia pomiarów współczynnika tarcia nawierzchni lotniskowych określają dokumenty międzynarodowe, takie jak: Załącznik 14 ICAO do Konwencji o Międzynarodowym Lotnictwie Cywilnym „Lotniska”. Tom I. Projektowanie i eksploatacja lotnisk, Doc-9157-AN/901 ICAO „Aerodrome Design Manual. Part 3. Pavements”, Federal Aviation Administration (FAA) „Advisory Circular No: 150/5320-12C” oraz dokument krajowy, którym jest opracowana przez Instytut Techniczny Wojsk Lotniczych (ITWL) norma obronna NO-17-A501:2015.

${ }^{\bowtie}$ mariusz.wesolowski@itwl.pl 
Wesołowski, M., Barszcz, P. i Blacha, K. (2017). Badania porównawcze urządzeń przeznaczonych do ciągłego pomiaru współczynnika tarcia nawierzchni elementów funkcjonalnych lotnisk. Acta Sci. Pol. Architectura, 16 (3), 137-145. doi: 10.22630/ ASPA.2017.16.3.14.

Nawierzchnie lotniskowe. Badania szorstkości. Dokumenty te określają wymagane wartości współczynnika tarcia dla nowych, użytkowanych i przeznaczonych do remontu nawierzchni lotniskowych. Ponadto definiują one ogólne wymagania dotyczące urządzeń pomiarowych stosowanych do określania współczynnika tarcia nawierzchni lotniskowych. Poprawność oceny właściwości przeciwpoślizgowych nawierzchni lotniskowych jest ważnym elementem bezpieczeństwa wykonywania operacji lotniczych. Akceptowalny poziom powtarzalności pomiaru współczynnika tarcia jest warunkiem koniecznym, ale niewystarczającym do zaakceptowania urządzenia do wykonywania pomiarów (Lewitowicz, Borgoń i Ząbkowicz, 1993).

Warunkiem (określonym przez doświadczenie i odbiorcę) dopuszczenia testera do wykonywania pomiarów współczynnika tarcia są wyniki przeprowadzonych badań, obejmujących korelację wyników pomiarów w odniesieniu do urządzeń, które są dopuszczone zgodnie z wyżej wymienionymi dokumentami, oraz:

- ocena sprawności technicznej urządzenia,

- procedura przygotowania urządzenia do pomiarów oraz jego kalibracji przed pomiarami,

- przeprowadzenie pomiarów współczynnika tarcia na wybranych odcinkach badawczych nawierzchni lotniskowych zakwalifikowanych jako nawierzchnie nowe, eksploatowane i do remontu w różnych warunkach pomiaru, tj. na sucho - pomiar bez wody i w warunkach na mokro - pomiar z wodą, pomiar przy prędkości $65 \mathrm{~km} \cdot \mathrm{h}^{-1}$ i pomiar przy prędkości $95 \mathrm{~km} \cdot \mathrm{h}^{-1}$,

- ocena poprawności wykonywania pomiarów,

- ocena powtarzalności uzyskiwanych podczas pomiarów parametrów na tych samych ściśle określonych odcinkach pomiarowych i na różnych nawierzchniach lotniskowych,

- ocena urządzeń pod kątem jakości wykonywanych pomiarów i ich zgodności z załącznikiem 14 ICAO oraz wymaganiami eksploatacyjno-technicznymi (WET),

- analiza uzyskanych wyników z wykorzystaniem aparatu statystycznego.

\section{CEL WYKONYWANIA POMIARÓW WSPÓŁCZYNNIKA TARCIA}

Celem prowadzonych badań było sprawdzenie poprawności działania dwóch testerów tarcia (oznaczonych jako T2 i T3) w porównaniu z testerem odniesienia (oznaczonym jako T1) w zakresie pomiaru współczynnika tarcia na określonych nawierzchniach lotniskowych. Proces oceny właściwości przeciwpoślizgowych nawierzchni elementów funkcjonalnych lotnisk (EFL) obejmuje również swoim zakresem urządzenia służące do pomiaru współczynnika tarcia (Grigoriu, 1991). Na rysunku 1 przedstawiono cechy charakteryzujące właściwości przeciwpoślizgowe nawierzchni lotnisk.

Nawierzchnie lotniskowe eksploatowane w Siłach Zbrojnych RP zostały wykonane z betonu asfaltowego lub cementowego, a na ich właściwości przeciwpoślizgowe ma wpływ ich konstrukcja i materiały, z jakich zostały one wykonane, a także zabiegi utrzymaniowe stosowane w ramach ich eksploatacji. Nawierzchnia może być w stanie suchym, czystym, mokrym lub być pokryta opadami czy osadami atmosferycznymi (Wytyczne nr 2 Prezesa Urzędu Lotnictwa Cywilnego z dnia 25 stycznia 2016 r. w sprawie metod oceny, pomiaru oraz raportowania stanu nawierzchni drogi startowej). Nawierzchnia EFL jest sucha lub czysta, jeżeli na całej jej powierzchni przeznaczonej do użytkowania nie znajdują się zanieczyszczenia i widoczne ślady wilgoci. Nawierzchnie suche lub czyste zapewniają poziom tarcia o nieznacznych różnicach, a wyniki pomiarów są ze sobą skorelowane i nie są dla nich wymagane szczególne kryteria dotyczące właściwości przeciwpoślizgowych. Powierzchnia nawierzchni EFL jest mokra, kiedy jest nasiąknięta wodą, ale nie znajdują się na niej zastoiska wody i zanieczyszczenia. Zjawisko nasiąkania powierzchni nawierzchni związane jest z odprowadzaniem wody, na który ma wpływ: kształt, nachylenie powierzchni, styk opona - ziemia, tzn. makrotekstura, wnikanie wody w nawierzchnię, tzn. mikrotekstura (Dz. Urz. Urzędu Lotnictwa Cywilnego z 2016 poz. 6).

Podwozie statku powietrznego, jako podsystem procesu oceny właściwości przeciwpoślizgowych, składa się z goleni, amortyzatora, piasty i opony oraz z systemu antypoślizgowego. Na statkach powietrznych stosuje się 
Wesołowski, M., Barszcz, P. i Blacha, K. (2017). Badania porównawcze urządzeń przeznaczonych do ciągłego pomiaru współczynnika tarcia nawierzchni elementów funkcjonalnych lotnisk. Acta Sci. Pol. Architectura, 16 (3), 137-145. doi: 10.22630/ ASPA.2017.16.3.14.

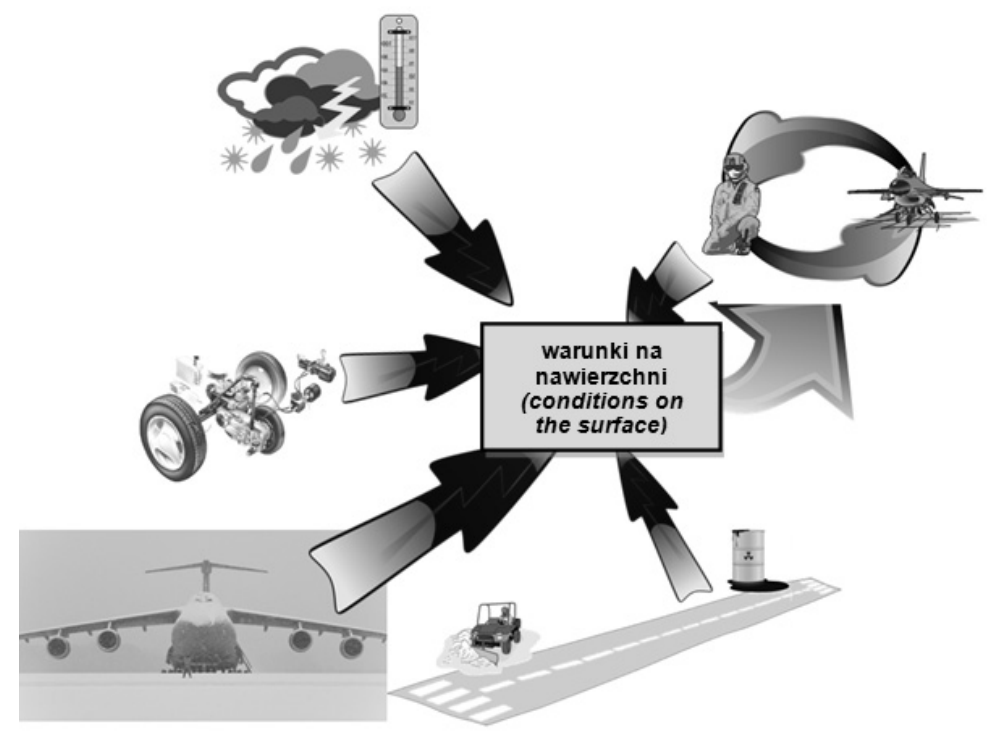

Rys. 1. Cechy charakteryzujące właściwości przeciwpoślizgowe nawierzchni elementów funkcjonalnych lotnisk

Fig. 1. Features characterizing the anti-skid properties of the surface of functional elements of airports

opony radialne, które charakteryzują się mniejszym ciężarem przy zwiększonej trwałości. Wprowadzając opony o nowszej konstrukcji, dąży się do osiągnięcia kompromisu pomiędzy trwałością a tarciem. Kształt bieżnika dobiera się w taki sposób, aby było zapewnione właściwe odprowadzenie wody z obszaru styku opona - nawierzchnia. Piasty kół wykonywane są z materiałów lekkich, takich jak stopy aluminium, i zazwyczaj z kutych stopów aluminium. Często stosuje się zabezpieczenie opony przed rozsadzeniem pod wpływem wysokiej temperatury poprzez stosowanie bezpieczników, które przy przekroczeniu temperatury krytycznej wytapiają się i zostaje wypuszczone powietrze z opony.

Elementy hamulców tarczowych stosowanych na statkach powietrznych wykonuje się z materiałów wytrzymałych i dobrze przewodzących ciepło. Zdolność pochłaniania energii hamowania jest bezpośrednio związana z rodzajem materiału i masą tarcz, maksymalny moment obrotowy zależy od liczby i średnicy tarcz, jak również od nacisku wywieranego na nie. Temperatura układu oraz prędkość, przy której następuje hamowanie, mają również wpływ na maksymalny moment obrotowy.

System antypoślizgowy jest układem stosowanym w celu przeciwdziałania blokowaniu kół podczas hamowania. Zapobiega on zjawiskom występującym po zablokowaniu kół, takim jak ściąganie samolotu w bok, a w efekcie utracie kontroli nad nim. Gdy zmniejsza się przyczepność pomiędzy oponą a nawierzchnią do poziomu, w którym moment obrotowy osiągnie wartość poniżej maksymalnego momentu obrotowego hamulca, to system antypoślizgowy monitorujący wskaźnik poślizgu kół reguluje ciśnienie na tłoku w celu osiągnięcia najlepszej skuteczności hamowania. Skuteczność systemu antypoślizgowego określa się na podstawie stosunku pomiędzy średnią siłą hamowania a teoretyczną maksymalną siłą hamowania uzyskaną przy optymalnym współczynniku poślizgu.

\section{PRZEBIEG POMIARU WSPÓŁCZYNNIKA TARCIA}

W celu uzyskania informacji o właściwościach pomiarowych testerów tarcia badania przeprowadzono na nawierzchniach wykonanych $\mathrm{z}$ betonu cementowego i asfaltowego przy prędkościach $65 \mathrm{i} 95 \mathrm{~km} \cdot \mathrm{h}^{-1} \mathrm{w}$ warunkach na sucho i na mokro (ITWL, 2014). Ocenie zostały poddane wszystkie testery tarcia, będące na wyposaże- 
Wesołowski, M., Barszcz, P. i Blacha, K. (2017). Badania porównawcze urządzeń przeznaczonych do ciągłego pomiaru współczynnika tarcia nawierzchni elementów funkcjonalnych lotnisk. Acta Sci. Pol. Architectura, 16 (3), 137-145. doi: 10.22630/ ASPA.2017.16.3.14.

niu Wojsk Lotniczych (rys. 2), urządzeniem odniesienia był tester szwedzkiej firmy ASFT (rys. 3), będący na wyposażeniu ITWL. Testery, które brały udział w badaniach porównawczych, znajdują się w wykazie ICAO (Organizacja Międzynarodowego Lotnictwa Cywilnego - ang. International Civil Aviation Organization).

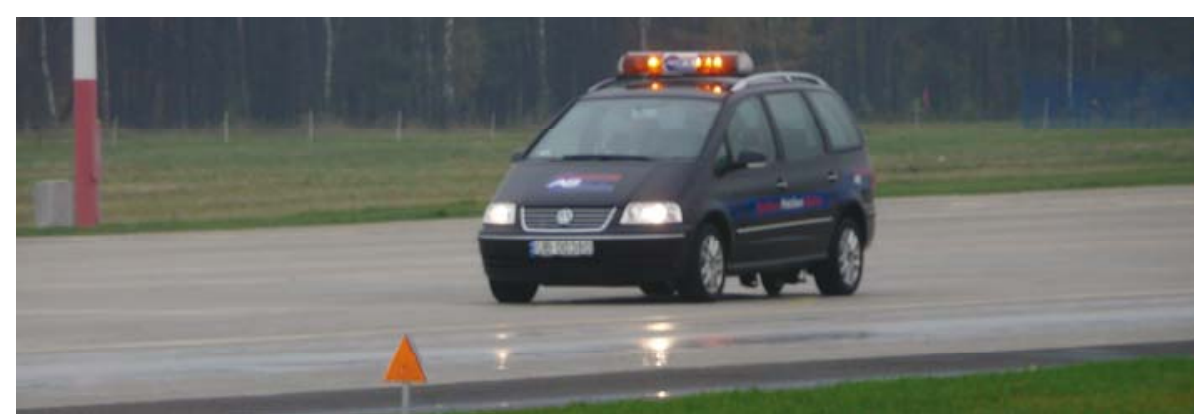

Rys. 2. Pomiar współczynnika tarcia nawierzchni elementu funkcjonalnego lotniska za pomocą testera tarcia firmy ASFT zbudowanego na samochodzie VW Sharan (ITWL, 2014)

Fig. 2. Measurement of the friction coefficient pavement elements functional airports using an ASFT friction tester built into a VW Sharan car (ITWL, 2014)

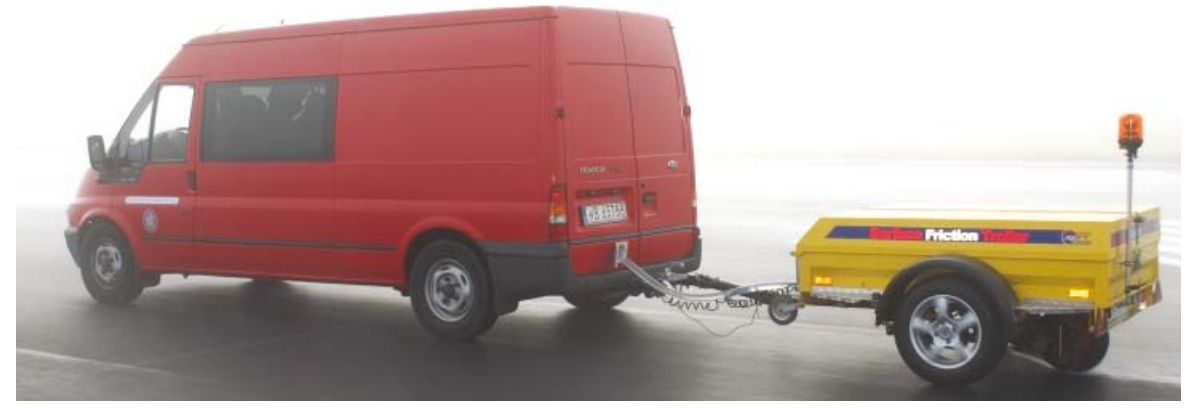

Rys. 3. Wykonywanie pomiarów współczynnika tarcia nawierzchni elementu funkcjonalnego lotniska z wykorzystaniem przyczepowego testera tarcia T-10 firmy ASFT (ITWL, 2014)

Fig. 3. Measurement of friction coefficient coefficient pavement elements functional airports using the ASFT T-10 Friction Tester (ITWL, 2014)

Podstawowymi kryteriami oceny była poprawność wykonywanych pomiarów oraz powtarzalność i odtwarzalność uzyskanych wartości współczynnika tarcia. Do testów przewidziano nawierzchnie lotniskowe różniące się: rodzajem materiału, z jakiego wykonano warstwę ścieralną (beton asfaltowy, beton cementowy), stanem nawierzchni (nowa - do 6 lat, w eksploatacji - od 10 do 22 lat, do remontu - powyżej 25 lat) oraz warunkami wykonania pomiaru (pomiar na sucho i mokro). Ocena uzyskanych wyników była przeprowadzona w dwóch etapach: etap I w miejscu prowadzenia badań, a etap II obejmował ich analizę. W etapie I akceptowalny poziom powtarzalności pomiarów współczynnika tarcia wynosił $\pm 0,03$.

Wszystkie urządzenia biorące udział w badaniach posiadały aktualne świadectwa wzorcowania kluczowych przetworników elektronicznych, mających wpływ na wielkość mierzonego współczynnika tarcia oraz rejestrujących warunki środowiskowe w trakcie wykonywania badań, jak również posiadały świadectwa sprawdzenia zespołów niepodlegających wzorcowaniu (np. system podawania wody). 
Wesołowski, M., Barszcz, P. i Blacha, K. (2017). Badania porównawcze urządzeń przeznaczonych do ciągłego pomiaru współczynnika tarcia nawierzchni elementów funkcjonalnych lotnisk. Acta Sci. Pol. Architectura, 16 (3), 137-145. doi: 10.22630/ ASPA.2017.16.3.14.

W przypadku urządzeń podlegających sprawdzeniu rola użytkownika przy wykonywaniu kalibracji sprowadzała się do zapewnienia właściwych warunków wykonywania kalibracji - teren poziomy z maksymalnym dopuszczalnym odchyleniem od osi wynoszącym $0,5 \%$. Sam proces kalibracji był wykonywany automatycznie i sterowany przez komputer pokładowy. Należy zaznaczyć, że kalibrację urządzeń należy przeprowadzać po wymianie opony przed rozpoczęciem pomiarów na każdym lotnisku oraz w przypadku stwierdzenia takiej potrzeby przez komisję podczas badań. Wszystkie informacje o przeprowadzonej przez użytkownika kalibracji i wymianie opony pomiarowej odnotowywano w protokole z pomiarów.

Odcinki pomiarowe, po których poruszały się testery tarcia podczas badań, były odmierzane na dystansie $100 \mathrm{~m}, \mathrm{z}$ wykorzystaniem nadzorowanego pod względem metrologicznym drogomierza elektronicznego. Przed wykonaniem badań na poszczególnych odcinkach testowych wszystkie tory pomiarowe były oczyszczone tak, aby nie występowały na nich luźne, drobne elementy, które mają wpływ na uzyskane wyniki. Wystarczającym zabiegiem było oczyszczenie powierzchni nawierzchni przy użyciu oczyszczarki lotniskowej.

\section{ANALIZA WYNIKÓW POMIARÓW}

Pomiary z wykorzystaniem testerów tarcia badanych i testera tarcia odniesienia dla określonych warunków prowadzono w 10 seriach po 5 pomiarów w serii (ITWL, 2014). Mając na uwadze analizę wyników pomiarów uzyskanych z wykorzystaniem badanych testerów tarcia oraz określenie liczby przejazdów w celu ich oceny, przeprowadzono analizę rozkładu uzyskanych wyników. Założenie o normalności rozkładu wyników pomiarów współczynnika tarcia z wykorzystaniem testerów zweryfikowano na podstawie testu Shapiro-Wilka, analizując statystykę $W$. Dla przyjętego poziomu prawdopodobieństwa, wynoszącego 0,05 , i dla liczby obserwacji w badaniu odczytano z tablicy wartość krytyczną, która wyniosła 0,842 . Krytyczna statystyka $W$ uzyskała wartość mniejszą od wartości obliczonych zgodnie ze wzorem na test $S-W$, na tej podstawie stwierdzono, że dla danego poziomu istotności otrzymane wyniki są istotne statystycznie, czyli zmienne mają rozkład zbliżony do rozkładu normalnego.

Minimalną liczność próby zweryfikowano na podstawie przeprowadzonej próby zerowej, którą potraktowano jako próbę wstępną. Na podstawie tej próby obliczono wartość średnią $\mu_{0}$ próby wstępnej:

$$
\mu_{0}=\frac{1}{n} \sum_{i=1}^{n} \mu_{i}
$$

a następnie obliczono kwadrat odchylenia standardowego próby wstępnej:

$$
\sigma^{2}=\frac{1}{n-1} \sum_{i=1}^{n}\left(\mu_{i}-\mu_{0}\right)^{2}
$$

Maksymalny dopuszczalny błąd szacunku $(d)$ dla pomiarów współczynnika tarcia nawierzchni lotniskowych wynosi połowę przedziału ufności $\pm 0,03$, a obliczone odchylenie standardowe wyniosło $\pm 0,02$. Oszacowano liczbę przejazdów przy współczynniku ufności wynoszącym 0,95 , dla którego $1-\alpha=0,95 \rightarrow \alpha=0,05$, gdzie na podstawie tablic rozkładu normalnego odczytano $u_{\alpha}=1,96$ i wyznaczono liczebność próby według wzoru (3) na minimalną liczebność próby dla estymacji średniej w populacji o rozkładzie normalnym (która wyniosła $n=7$ ):

$$
n \geq \frac{u_{\alpha}^{2} \cdot \sigma^{2}}{d^{2}}
$$

Z przeprowadzonych badań wynikło, że współczynnik tarcia zmierzony z wykorzystaniem testerów tarcia biorących udział w badaniach osiągnął dla tych samych warunków badawczych różne wartości (ITWL, 2014), jednak biorąc pod uwagę kryterium, jakim jest powtarzalność, to wyniki mieściły się w zakresie $\pm 0,02$, oraz 
Wesołowski, M., Barszcz, P. i Blacha, K. (2017). Badania porównawcze urządzeń przeznaczonych do ciągłego pomiaru współczynnika tarcia nawierzchni elementów funkcjonalnych lotnisk. Acta Sci. Pol. Architectura, 16 (3), 137-145. doi: 10.22630/ ASPA.2017.16.3.14.

odtwarzalność, to wyniki mieściły się w zakresie $\pm 0,07$. Badania porównawcze polegają na porównaniu wyników pomiarów testerów sprawdzanych z wynikami uzyskanymi przez tester odniesienia, w związku z tym wykreślono proste regresji w celu wyznaczenia skorygowanego współczynnika tarcia, co przedstawiono na rysunkach 4-7. Główną ideą regresji jest określanie współczynnika tarcia skorygowanego na podstawie współczynnika tarcia zmierzonego z wykorzystaniem eksploatowanych testerów.

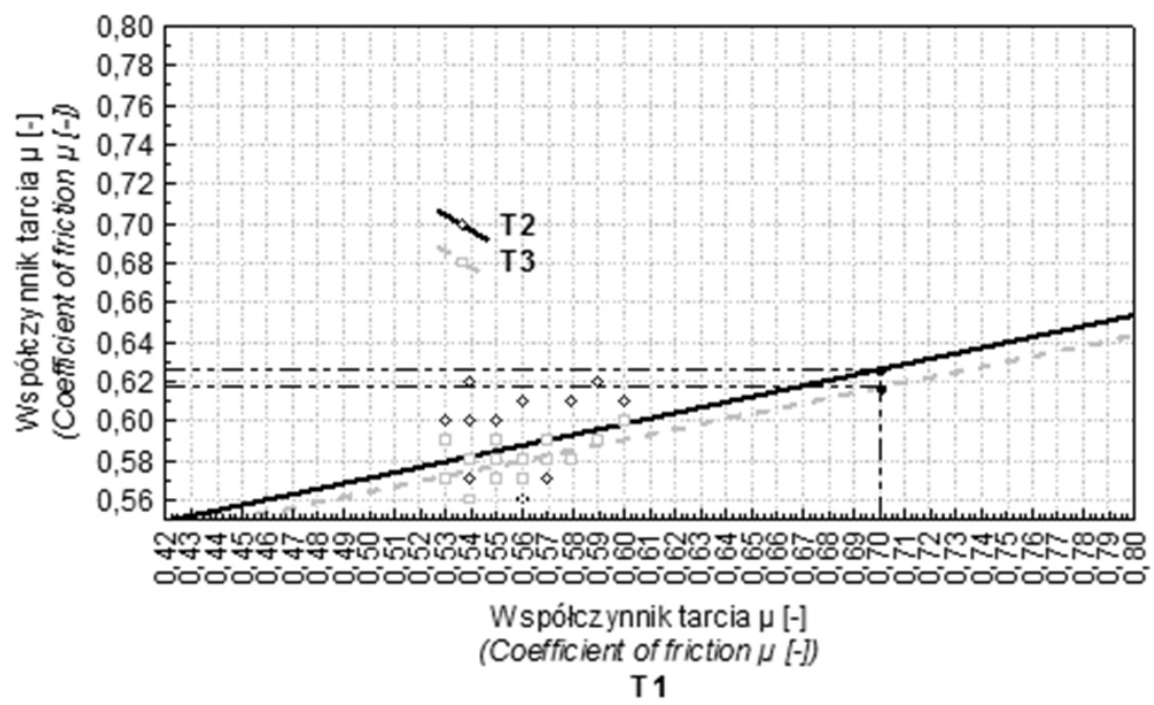

Rys. 4. Wyznaczanie współczynnika tarcia skorygowanego na podstawie wyznaczonych prostych regresji w zależności od warunków prowadzenia pomiarów $-65 \mathrm{~km} \cdot \mathrm{h}^{-1}$ na sucho, beton cementowy

Fig. 4. Determination of the coefficient of friction corrected based on the determined simple regression, depending on the measurement conditions $-65 \mathrm{~km} \cdot \mathrm{h}^{-1}$ on dry, cement concrete

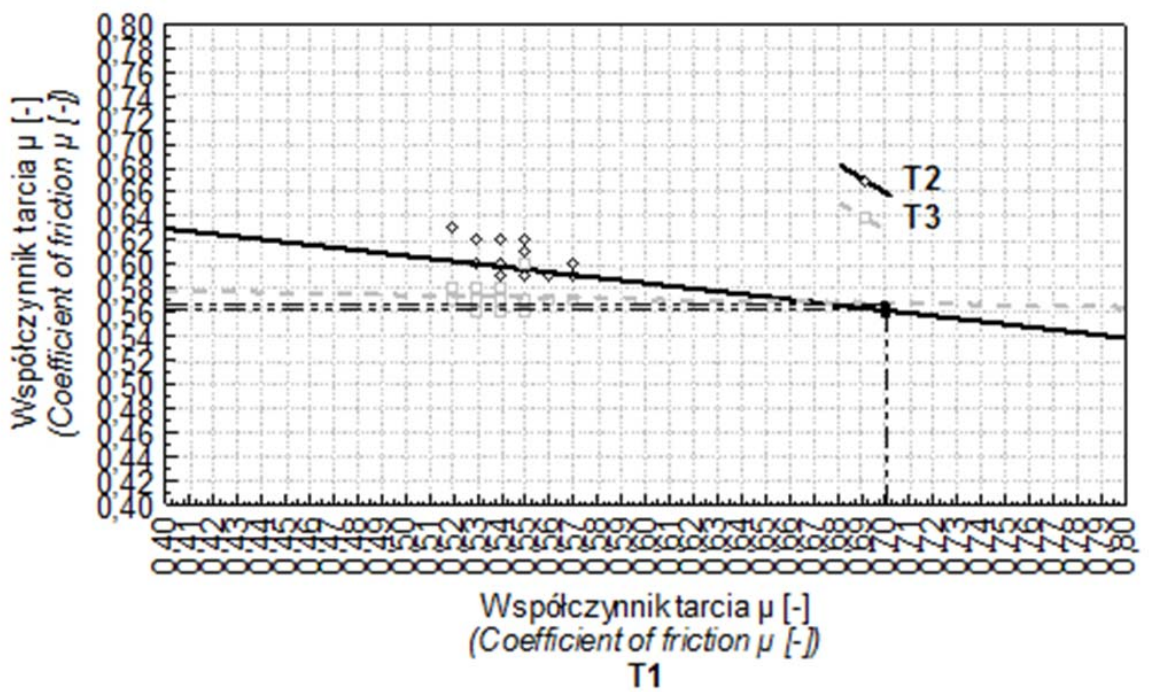

Rys. 5. Wyznaczanie współczynnika tarcia skorygowanego na podstawie wyznaczonych prostych regresji w zależności od warunków prowadzenia pomiarów $-65 \mathrm{~km} \cdot \mathrm{h}^{-1}$ na mokro, beton cementowy

Fig. 5. Determination of the coefficient of friction corrected based on the determined simple regression, depending on the measurement conditions $-65 \mathrm{~km} \cdot \mathrm{h}^{-1}$ on wet, cement concrete 
Wesołowski, M., Barszcz, P. i Blacha, K. (2017). Badania porównawcze urządzeń przeznaczonych do ciągłego pomiaru współczynnika tarcia nawierzchni elementów funkcjonalnych lotnisk. Acta Sci. Pol. Architectura, 16 (3), 137-145. doi: 10.22630/ ASPA.2017.16.3.14.

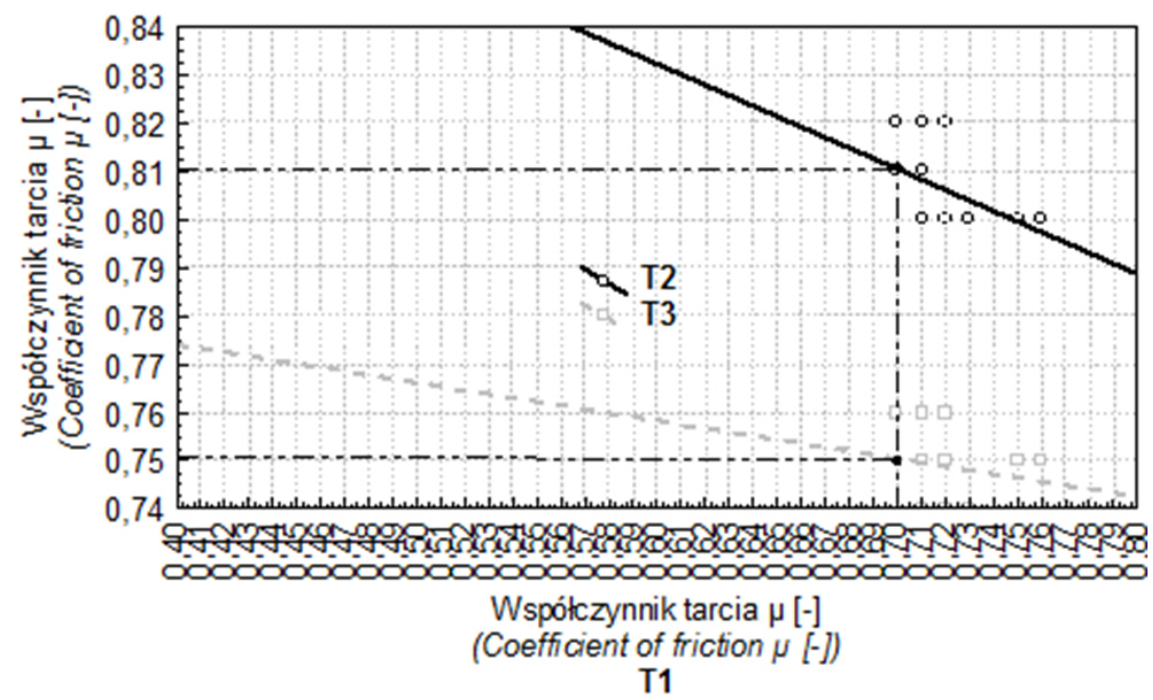

Rys. 6. Wyznaczanie współczynnika tarcia skorygowanego na podstawie wyznaczonych prostych regresji w zależności od warunków prowadzenia pomiarów $95 \mathrm{~km} \cdot \mathrm{h}^{-1}$ na sucho, beton asfaltowy

Fig. 6. Determination of the coefficient of friction corrected based on the determined simple regression, depending on the measurement conditions $-95 \mathrm{~km} \cdot \mathrm{h}^{-1}$ on dry, asphalt concrete

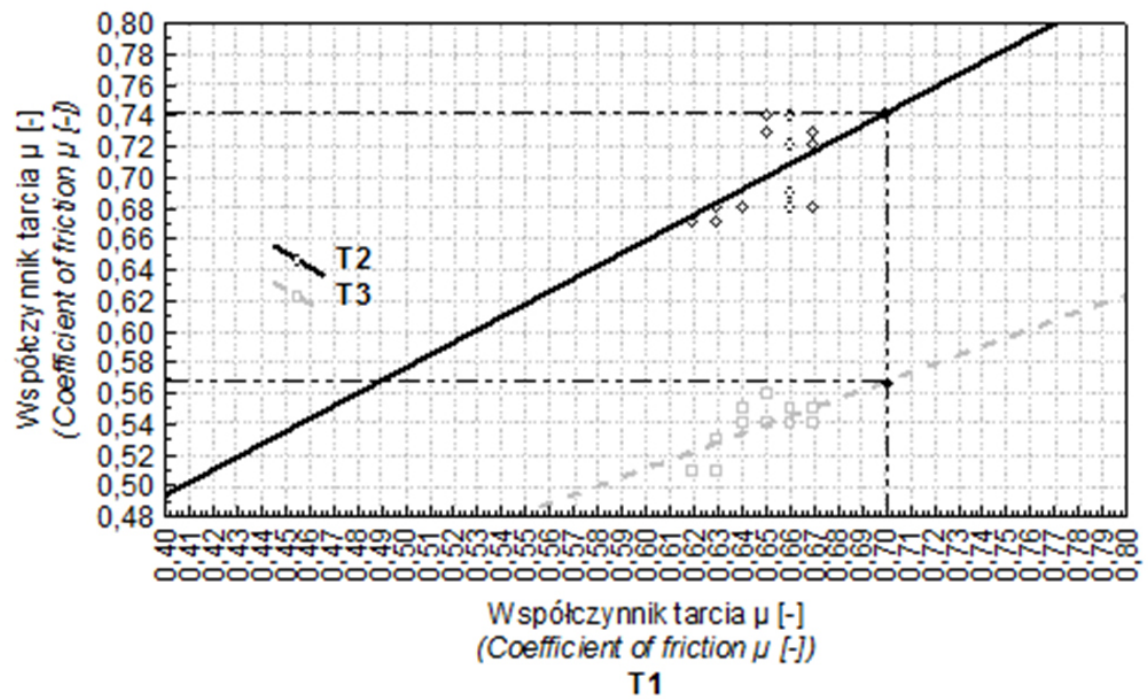

Rys. 7. Wyznaczanie współczynnika tarcia skorygowanego na podstawie wyznaczonych prostych regresji w zależności od warunków prowadzenia pomiarów $-95 \mathrm{~km} \cdot \mathrm{h}^{-1}$ na mokro, beton asfaltowy

Fig. 7. Determination of the coefficient of friction corrected based on the determined simple regression, depending on the measurement conditions $-95 \mathrm{~km} \cdot \mathrm{h}^{-1}$ on wet, asphalt concrete

Ocenę skuteczności systemu pomiarowego można przeprowadzić, wykorzystując metodę R\&R. Głównym elementem metody R\&R jest wyznaczenie wskaźnika R\&R (powtarzalność i odtwarzalność), które odbywa się przez pomiar wybranego wyrobu z wykorzystaniem określonego systemu pomiarowego. Podstawowym celem przeprowadzania analizy R\&R jest ustalenie przyczyn zmienności procesu pomiaru po to, aby można było zinterpretować 
Wesołowski, M., Barszcz, P. i Blacha, K. (2017). Badania porównawcze urządzeń przeznaczonych do ciągłego pomiaru współczynnika tarcia nawierzchni elementów funkcjonalnych lotnisk. Acta Sci. Pol. Architectura, 16 (3), 137-145. doi: 10.22630/ ASPA.2017.16.3.14.

i zminimalizować ich wpływ. Metoda ta uwzględnia analizę zróżnicowania pomiarów przyrządów pomiarowych (powtarzalność) i wahania pomiarów wykonywanych przez operatorów (odtwarzalność).

Ocenę systemu pomiarowego przeprowadza się poprzez sprawdzenie wartości \%R\&R:

$$
\% R \& R=\frac{\sigma_{m}}{\sigma_{p}} \cdot 100=\frac{R \& R}{E V} \cdot 100
$$

Gdy ta wartość jest mniejsza niż $10 \%$, to system jest do zaakceptowania, gdy wynosi $10-30 \%$ - system może być zaakceptowany warunkowo, gdy przekracza 30\% - system pomiarowy jest nie do zaakceptowania, konieczne jest udoskonalenie.

\section{WNIOSKI}

W publikacji przedstawiono ogólnie problematykę procesu oceny przydatności systemów służących do pomiaru współczynnika tarcia nawierzchni elementów funkcjonalnych lotnisk, w których skład wchodzą urządzenia pomiarowe i operatorzy, poprzez analizę kryterium, jakim jest powtarzalność $\left(\sigma_{p}= \pm 0,02\right)$ i odtwarzalność $\left(\sigma_{o}= \pm 0,07\right)$. Urządzenia służące do pomiaru współczynnika tarcia nawierzchni lotniskowych muszą gwarantować poprawność uzyskiwanych wyników, gdyż od oceny właściwości przeciwpoślizgowych bezpośrednio zależy decyzja podjęta przez pilota o sposobie wykonania manewru lądowania, co ma bezpośrednie przełożenie na bezpieczeństwo wykonywania operacji lotniczych, bezpieczeństwo załogi i pasażerów. Na ocenę przydatności urządzeń składają się wyniki badań porównawczych realizowanych w terenie, całokształt problemów technicznych związanych z procesem sprawdzenia, przygotowania urządzeń do prowadzenia pomiarów oraz samych pomiarów. Warunkiem dopuszczenia urządzenia nieujętego w wykazie ICAO do wykonywania pomiarów współczynnika tarcia nawierzchni lotniskowych są badania porównawcze w odniesieniu do urządzenia, które na tym wykazie się znajduje, wykorzystując do tego aparat statystyczny. Na podstawie przeprowadzonych obserwacji można stwierdzić, że wartości zmierzonego współczynnika tarcia przez badane urządzenia w dużym stopniu zależą od poziomu wyszkolenia operatorów oraz znajomości budowy i obsługi urządzenia.

$\mathrm{Z}$ doświadczenia autorów, zdobytego podczas badań testerów tarcia mierzących współczynnik tarcia nawierzchni lotniskowych, wynika, że testery powinny być poddawane badaniom porównawczym przynajmniej raz w roku, przed rozpoczęciem zimowego utrzymania lotnisk w celu określenia stanu technicznego testerów tarcia i oceny przygotowania operatorów do wykonywania pomiarów. $\mathrm{Z}$ analizy systemu pomiarowego T2 wynika, że może on być zaakceptowany warunkowo przy prowadzeniu badań na mokro ( $\% R \& R=12$ - pomiar przy prędkości $65 \mathrm{~km} \cdot \mathrm{h}^{-1}$ na mokro, $\% R \& R=20$ - pomiar prowadzony przy prędkości $95 \mathrm{~km} \cdot \mathrm{h}^{-1}$ na mokro). Natomiast $\mathrm{z}$ analizy systemu pomiarowego $\mathrm{T} 3$ wynika, że jest on do zaakceptowania przy prowadzeniu badań na mokro $\left(\% R \& R=6\right.$ - pomiar przy prędkości $65 \mathrm{~km} \cdot \mathrm{h}^{-1}$ na mokro, $\% R \& R=8$ - pomiar prowadzony przy prędkości $95 \mathrm{~km} \cdot \mathrm{h}^{-1}$ na mokro). Wskazane jest jednak uwzględnianie poprawki zgodnie $\mathrm{z}$ wykresami zamieszczonymi w artykule.

\section{PIŚMIENNICTWO}

Grigoriu, M. (1991). Expert systems for maintenance engineering. Materiały Konferencji Artificial Techniques for Improving Aicraft Maitenance Efficiency.

ITWL - Instytut Techniczny Wojsk Lotniczych (2014). Sprawozdanie Nr 30/24/2014. Warszawa: ITWL.

Jaźwiński, J. i Borgoń, J. (1989). Niezawodność eksploatacyjna i bezpieczeństwo lotów. Warszawa: Wydawnictwo KiŁ.

Lewitowicz, J., Borgoń, J. i Ząbkowicz, W. (1993). Problemy badań i eksploatacji techniki lotniczej. Warszawa: Wydawnictwo ITWL. 
Wesołowski, M., Barszcz, P. i Blacha, K. (2017). Badania porównawcze urządzeń przeznaczonych do ciągłego pomiaru współczynnika tarcia nawierzchni elementów funkcjonalnych lotnisk. Acta Sci. Pol. Architectura, 16 (3), 137-145. doi: 10.22630/ ASPA.2017.16.3.14.

NO-17-A501:2015. Nawierzchnie lotniskowe. Badania szorstkości.

Wytyczne nr 2 Prezesa Urzędu Lotnictwa Cywilnego z dnia 25 stycznia 2016 r. w sprawie metod oceny, pomiaru oraz raportowania stanu nawierzchni drogi startowej (Dz.U. Urzędu Lotnictwa Cywilnego z 2016 poz. 6).

Załącznik 14 do konwencji o międzynarodowym lotnictwie cywilnym (2013). Lotniska. Tom I. Projektowanie i eksploatacja lotnisk. Wydanie VI. Organizacja Międzynarodowego Lotnictwa Cywilnego (ICAO).

\section{COMPARISON OF TESTING EQUIPMENT FOR CONTINUOUS MEASUREMENT OF THE FRICTION COEFFICIENT OF AIRPORTS FUNCTIONAL ELEMENTS' PAVEMENT}

\section{SUMMARY}

The coefficient of friction measuring devices must ensure the correctness of the results, since the assessment of the anti-skid properties of the pavement surfaces affect the pilot's decisions upon the landing maneuver. Accepted repeatability of measurements at the level of \pm 0.03 and reproducibility at the level of \pm 0.07 is not a sufficient condition for acceptance of the measurement system. The paper presents an approach to evaluating systems that measure friction coefficient of pavement of functional elements of airports. Measurements for specific conditions were made in 10 series, on cement and asphalt concrete surfaces, at $65 \mathrm{~km} \cdot \mathrm{h}^{-1}$ and $95 \mathrm{~km} \cdot \mathrm{h}^{-1}$, under dry and wet conditions. The assumption of normality of distributions was verified based on the Shapiro-Wilk test by analyzing $W$ statistics. It has been observed that the coefficient of friction measured using the friction testers attained different values for the same test conditions. Considering the reference tester, straight regression lines were plotted to determine the corrected coefficient of friction.

Key words: airfield pavement, friction tester, anti-skid properties 